\title{
Drinking water quality and its resources with three different technologies
}

Safinaz A. Farfour, Nashwa M. H. Rizk, AymanS. El-Dourghamy, Ibrahim E. Mousa*

Department of Environmental Biotechnology, Genetic Engineering and Biotechnology Research

Institute, University of Sadat City, Menofiya, 22857 Egypt

*Corresponding author: ibrahim.mousa@gebri.usc.edu.eg

\begin{abstract}
Surfacewater and ground water are the basic resources of drinking water insuburban area. Three kinds of waters and were monitored to differentiate its suitability for drinking waters through different technologies used to treat. For three waters characterized results, biologicalindicators were moderate loads. While, chemical analyses were recorded different water quality indices (WQI). All of the collected samples showed significant improvements in total solids. The only sample that showed slight increases in total solids was the raw water from the surface compared to the other two groundwater resources. In case of system operating with only chlorination for groundwater, increased dosing loads resulted in a bad taste that required GAC filtration units after. In a GAC/RO system operating in water conditions ( $<500$ TDS), reducing the treatment efficiency loading rate to $45 \%$ from $60-80 \%$ was important for achieving effluent quality more than $150 \mathrm{mg} / \mathrm{L}$ during events of low TDS content. The performance of both sedimentation/filtration systems was highly dependent on the biological maturity of the system and surface water quality.
\end{abstract}

Keywords: Drinking water; resources; sand filtration; chlorination; Reverse osmosis; metals.

\section{INTRODUCTION}

Egypt is one of the countries facing great challenges, due to its limited water resources represented mainly by its fixed share of the Nile water and its aridity which is the general characteristic of the country (Moghazy et al., 2015).To face these problems of water shortage, the government of Egypt has initiated major programs to improve the performance of the water system of the old lands in the Nile Delta (MWRI 2009).

Water resources quality commonly focuses on nutrients, microbial pollutants, heavy metals, and priority pollutants. However, recent research reveals the presence of a multitude of organic contaminants that significantly affect water quality. These contaminants originate from diverse sources and typically in concentrations that range from $\mathrm{ng} / \mathrm{L}$ to $\mathrm{g} / \mathrm{L}$ (Pale et al., 2014). Naturalattenuation and conventional treatment processes are not capable of removing these micropollutants from wastewater and surface and drinking water and are reported to bioaccumulate in macro invertebrates, other organisms in the aquatic food web and humans (Ruhí et al., 2015; Huerta et al., 2015; Annamalai and Namasivayam 2015). Only $1 \%$ is available on earth for drinking purpose, agricultural purposedomestic purpose, power generation, industrialconsumption, transportation and waste disposal (Tahir et al., 2008).

Major part of the world's water is seawater, brackish water and groundwater. Approximately, $97.4 \%$ of the entire water available on earth is salty and $1.984 \%$ is 
located in the ice caps and glaciers, while $0.592 \%$ is located as groundwater and only $0.014 \%$ of the earth's water is available as fresh water (Kalogirou, 2005). Many waterstressed countries are supplementing their fresh water supply with desalinated water to meet their increased water demand caused by population growth, rapid urban sprawl, agriculture development, industrialization, and tourism (Ghaffour et al., 2013).

Ultra-filtration (UF) was found to be cost effective and efficient technique for the removal of suspended solids and bacteria (Arras et al., 2009). The selection of the pretreatment option is site specific and is mainly based on feed water quality, but in some cases the feed water quality is influenced by seasonal variation (i.e. flood, drought, and climatic impact) which make pre-treatment design more complicated. Forward osmosis (FO) was found to be a feasible pre-treatment option for variable quality feed water and for the feed having high fouling potential. It is capable of providing uniform treated water quality with less fouling potential instead of variable feed quality (Khanzada et al., 2017).

Water pollution not only affects water quality but also cause threats to human health, economic development and social well-being. Groundwater aquifers are highly vulnerable to pollution due to recharging of domestic, industrial and agricultural waste water; therefore, it is significant to control water pollution and monitor water quality (Arivarasi and Ganesan, 2017). Urbanization, industrialization and the unregulated growth of the population have altered the landscape of many urban and peri-urban areas. Changes in land use pattern, local topography and drainage systems directly affect both quality and quantity of groundwater.

The level of contamination tend to be highest during rains, however, the low water volume during dry seasons also result to rise in concentration per water volume for certain contaminants. Therefore, any bacteriological water quality treatment measure needs take into account the intensity of rainfall. This will provide adequate knowledge on the appropriate treatment approach to apply for efficient water quality improvement (Richard et al., 2016).

This study aimed to screen the changes in physical, Chemical and biological parameters during production of drinking waters. Treatment process in raw, clarified, filtered and treated water treatment processes in between conventionally treated methods and new technology (Reversal Osmosis technology) were monitored. Detection of the removal percentage and comparison to Egyptian guidelines were investigated. The effectiveness of this systems was verified by observing the effluent content such as microbial load during an operation periods, total element content (ICP-MS), total suspended Solids (TSS), $\mathrm{pH}$ and total dissolved solids (TDS). 


\section{MATERIALS AND METHODS}

All powdered chemicals were reagent grade (> 99\% pure). $\mathrm{NaCl}, \mathrm{CaCl}_{2} .2 \mathrm{H}_{2} \mathrm{O}$, $\mathrm{NaHCO}_{3}, \mathrm{FeSO}_{4} .7 \mathrm{H}_{2} \mathrm{O}$ and $\mathrm{MnsO}_{4} . \mathrm{H}_{2} \mathrm{O}$ were supplied by Fisher Scientific (Fair Lawn, NJ). Nitric acid $\left(\mathrm{HNO}_{3}, 67-70 \%\right)$ and $\mathrm{KMnO}_{4}$ were purchased from Alpha chemicals. (India). The commercial sodium hypochlorite ( $\mathrm{NaOCl}, 8 \%$ (W/V) available chlorine) bleach solution was diluted to produce a stock solution $(120 \mathrm{mg}$ $\mathrm{Cl} 2 / \mathrm{L})$. Ultrapure water (Milli-QTM) from Purelab - ELGA - Veolia, UK, was used to prepare all stock solutions.

\section{Water resources and drinking water}

\section{treatment plants}

Three kinds of water were monitored to differentiate its drinking waters. The first plant was Badr drinking water treatment plant (BDWTP) in El-Berhira governorate, Egypt which abstracts its water from El-Rayah ElNassary Canal (RNC) intake point of raw surface water of Badr plant is coastal one which attached directly to the plant and transferred water from the river bank to the station. The second type was direct ground water sources which chlorinated before distribution. The last one is compact units that abstract its water from ground water and use reverse osmosis technology for treatment.

\section{Samplingofwater}

Raw, clarified, filtered and treated water samples were collected from inside Badr drinking water treatment plant for a full 5 seasons between March, 2017 and June, 2018 following the standard methods for the examination of water and wastewater (APHA, 2005). water samples were weekly collected for various physical, chemical, bacteriological and algal count analyses in addition to experiments for calculation doses of Alum (jar test) and residual chlorine (break point test). All samples were analyzed about 2 hours from collection and duplicated to get more accuracy.

\section{Physiochemical analyses}

The quality of resource water samples was determined after some measurements such as $\mathrm{pH}$ (2510 platinum electrode), turbidity as Nephelometric turbidity units (NTU) (2130), chloride (mg/l) (4500 Argentometeric method), total alkalinity $(\mathrm{mg} / \mathrm{l})$ (2320B titration method), total Hardness (mg/l) (2340B EDTA titration), silicate (mg/l) (4500C Molybdosilicate method), phosphate $(\mathrm{mg} / \mathrm{l})$ (4500D Stannous chloride method), sulfate (mg/l) (4500E Turbidimetric method). Nitrogen forms as free ammonia (mg/l) (4500C Sodium Nitroprossiude method), and Nitrite (4500B colorimetric method) were measured. All the physicochemical analyses were in duplicates and determined by the procedures recommended in the standard methods for the examination of water and wastewater (APHA, 2005).

\section{Microbiological analyses}

Water samples were collected in glass bottles that have been cleansed and rinsed carefully, given a final rinse with distilled water, and sterilized by autoclave at $121^{\circ} \mathrm{C}$ for 15 min. Analysis was initiated as soon as possible after collection to minimize changes in bacterial population. The enumeration of total bacterial count (TBC) and total coliform (TC) in water samples was done using the spreading plate and separation membrane techniques. Tryptone glucose yeast agar medium and $\mathrm{m}$ Endo broth (Oxoid, Basingstoke, Hampshire, England) were used for TBC and V, respectively. Additional blanks were prepared to determine contamination of plates, pipets, and room air. Sterility of medium and dilution 
water blanks was checked by pouring control plates for each series of samples. Additional controls were prepared to determine contamination of plates, pipets, and room air (APHA, 2005).

\section{Water Quality Index for Drinking}

Water Quality Index was calculated based on the relative weight of each physicochemical parameter. The values of WQI of the samples were found in the range of 27-114 in post-monsoon season while it was $26-131$ in the pre-monsoon season.

\section{Removal Efficiency}

It is important to be able to evaluate the rate at which contaminants are removed in order to design the full scale application of the technology (Mousa, 2016). Pollutant removal efficiency was calculated by the following equation:

\section{RESULTS AND DISCUSSION}

In the sand filtration water treatment processes, the coagulation and flocculation processes produce sludge according to the level of the water turbidity. All of the collected samples showed significant improvements in total solids. The only sample that showed slight

$$
\text { Removal \% }=\frac{C 0-C t}{C 0} * 100
$$

where $\mathrm{Co}$ is the initial pollutant concentration $(\mathrm{mg} / \mathrm{L})$ and $\mathrm{Ct}$ is pollutant concentration at a defined time during treatment $(\mathrm{mg} / \mathrm{L})$.

\section{Data analysis}

The collected data on the physicchemical parameters, density of indicator were appropriately subjected to statistical analysis to find their corresponding mean variations. Graphs and chats were constructed using MS office Excel version 2013 and Statistical Package for Social Sciences (SPSS) version 17 software was used in the analysis. 95\% level of significance was used as the critical point $(P=<0.05)$.

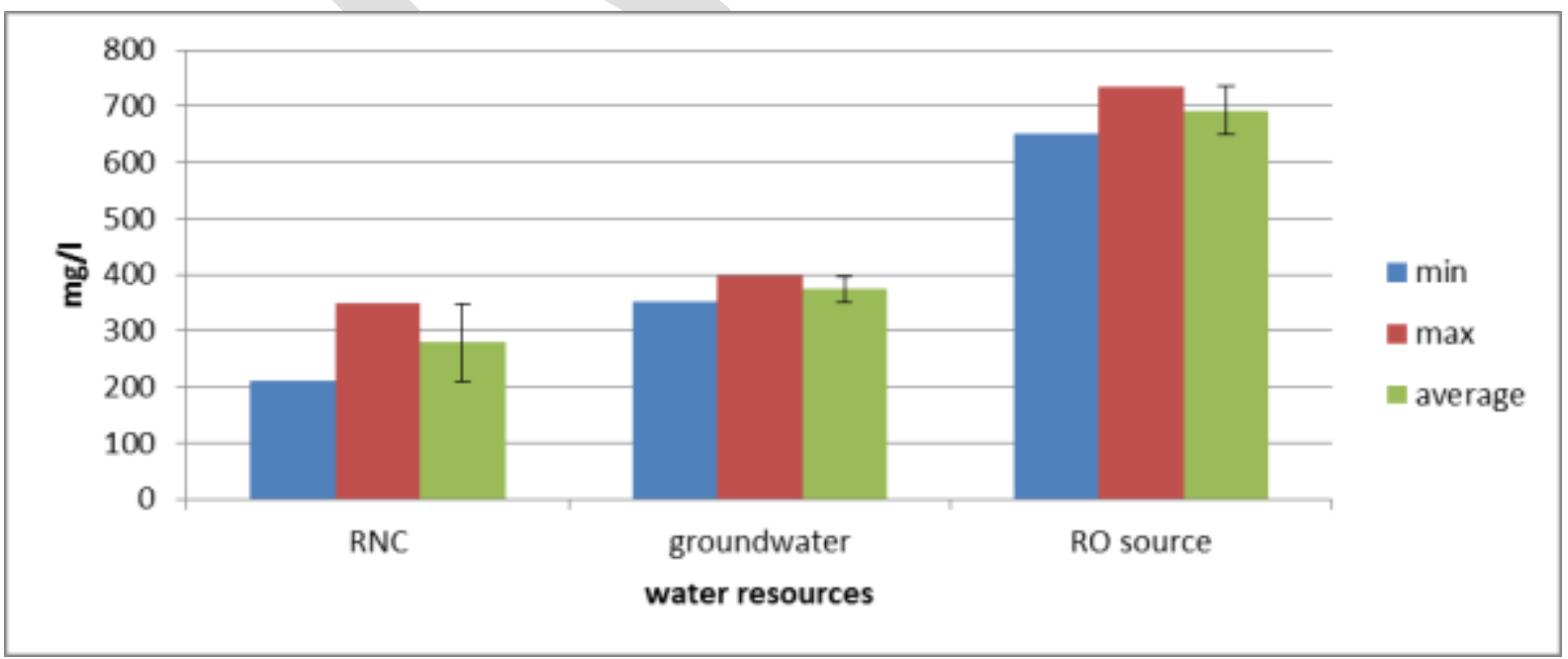

Figure 1: Total dissolved solids of different water resources used for drinking water production through studying period of March, 2017 and June, 2018. 
This raw water sample was characterized by a low water turbidity. But the improvement in sedimentation was significant effects. The aluminum sulfate is the most common coagulant used in water treatment plants that depend on surface resources Badr region. It is

Table 1: Physiochemical and biological characterization of surface water abstracted from RNC and removal efficiency of Badr drinking water.

\begin{tabular}{|c|c|c|c|c|c|}
\hline \multirow{2}{*}{ Elements } & \multicolumn{2}{|c|}{ Raw water } & \multicolumn{2}{|c|}{ Treated water } & \multirow{2}{*}{ Removal \% } \\
\hline & Average & SD & Average & SD & \\
\hline Fecal coliform count (CFU/100 ml) & 5.04 & 38.02 & 0 & 0 & 100 \\
\hline Total Algal count (unit/L) & 2265 & 416 & 4 & 3 & 99.82 \\
\hline Total coliform confirmed test (CFU/100 ml) & 479 & 334 & 0 & 0 & 100 \\
\hline Total bacterial count (CFU/ml) & 84 & 14 & 0.44 & 1.08 & 99.48 \\
\hline Total iron $(\mathrm{Fe})(\mathrm{mg} / \mathrm{l})$ & 0.08 & 0.04 & 0 & 0 & 100 \\
\hline Manganese (Mn) (mg / l) & 0.09 & 0.03 & 0 & 0 & 100 \\
\hline Ammonia- $\mathrm{N}(\mathrm{mg} / \mathrm{l})$ & 0.11 & 0.03 & 0 & 0 & 100 \\
\hline Nitrite-N (mg / l) & 0.019 & 0.027 & 0 & 0 & 100 \\
\hline Turbidity (NTU) & 8.52 & 2.1 & 0.4 & 0.08 & 95.31 \\
\hline Phosphate-P (mg / I) & 0.27 & 0.09 & 0.2 & 0.14 & 25.93 \\
\hline Total alkalinity (CaCO3 / I) & 145.81 & 13.92 & 126.23 & 14.67 & 13.43 \\
\hline$\overline{\mathrm{pH}}$ & 7.77 & 0.24 & 7.31 & 0.13 & 5.92 \\
\hline Total hardness (CaCO3 / I) & 149.72 & 10.83 & 149.71 & 10.76 & 0.0066 \\
\hline Residual chlorine (mg / l) & 0 & 0 & 2.55 & 0.36 & 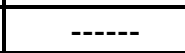 \\
\hline Aluminum (Al) $(\mathrm{mg} / \mathrm{I})$ & 0 & 0 & 0.08 & 0.01 & ---------- \\
\hline Calcium hardness $(\mathrm{CaCO} 3 / \mathrm{l})$ & 82.88 & 9.07 & 83.03 & 9.00 & -0.18 \\
\hline Electrical Conductivity $(\mathrm{EC})(\mu \mathrm{S} / \mathrm{cm})$ & 387.06 & 32.02 & 398.15 & 32.4 & -2.86 \\
\hline Total dissolved solids (TDS) (mg / l) & 259.45 & 21.46 & 266.68 & 21.74 & -2.78 \\
\hline Silica $(\mathrm{mg} / \mathrm{l})$ & 5.68 & 3.13 & 7.16 & 2.37 & -26.05 \\
\hline Sulfate (SO4) (mg / l) & 31.84 & 4.17 & 44.76 & 4.84 & -40.57 \\
\hline Chlorides (mg / I) & 19.45 & 3.37 & 37.86 & 5.72 & -94.65 \\
\hline
\end{tabular}

In this study, the effectiveness of sludge was evaluated at different turbidity levels (low, medium and high turbidity) and coagulant dosage to find optimal operational conditions. The influence of settling time was also studied. A set of Jar test experiments was conducted to find the sludge and aluminum sulfate dosages in order to improve the produced water quality difficult to manage sludge produced by the treatment plant. However, it can be used in the process to improve the quality of the treated water and reduce the aluminum sulfate doseas shown in Table 1. for different turbidity levels. Also, another objective of this study is to provide water treatment operators with a tool that enables to predict and replace, sometimes, the manual method (Jar testing) used in this plant to predict the optimum coagulant doseas shown in Figure 2. 


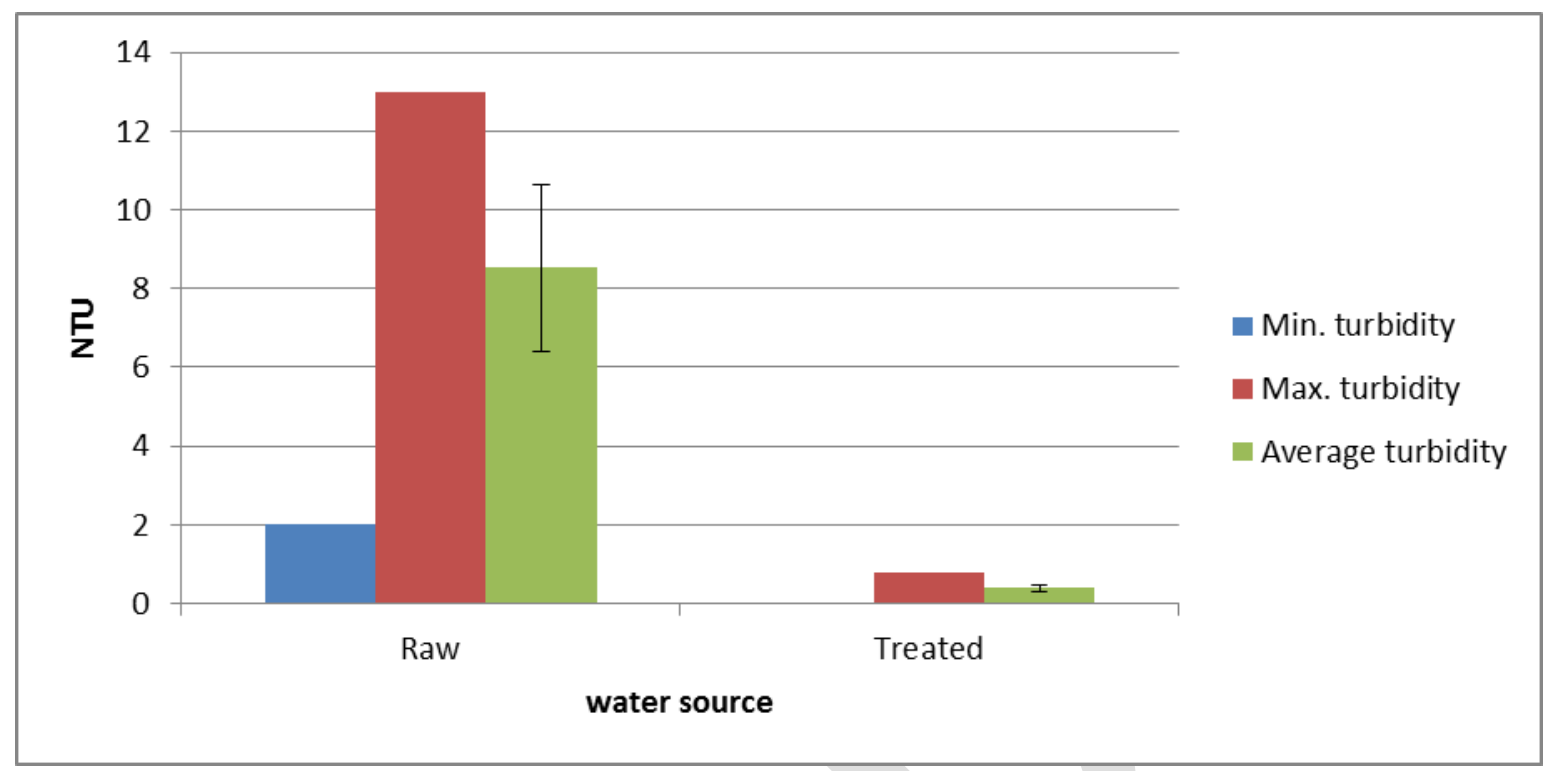

Figure 2: Turbidity of different water sourceof Badr station for drinking water production through studying period of March, 2017 and June, 2018.

Results demonstrated that reusing sludge produced by the treatment plant can improve the quality of the produced water and reduce the aluminum sulfate using (turbidity removal up $99,47 \%)$. The aluminum sulfate dosage can be reduced from 40 to $50 \%$ according to the turbidity level. Also, it is possible to construct a model using actual process data from water treatment plant located in Meknes, Morocco. of manganeseandiron ions were performed by $97.08 \%$ and $82.27 \%$, respectively. Through Adsorption of $\mathrm{Mn}$ (II) onto $\mathrm{MnOx}$ (s)-coated sand which is normally performed in packed bed contactors operated at relatively low HLRs (6$12 \mathrm{~m} / \mathrm{h}$ ) to remove low feed water $\mathrm{Mn}(\mathrm{II})$ concentrations (<0.5 mg/L) (Piispanen and Sallanko, 2010).

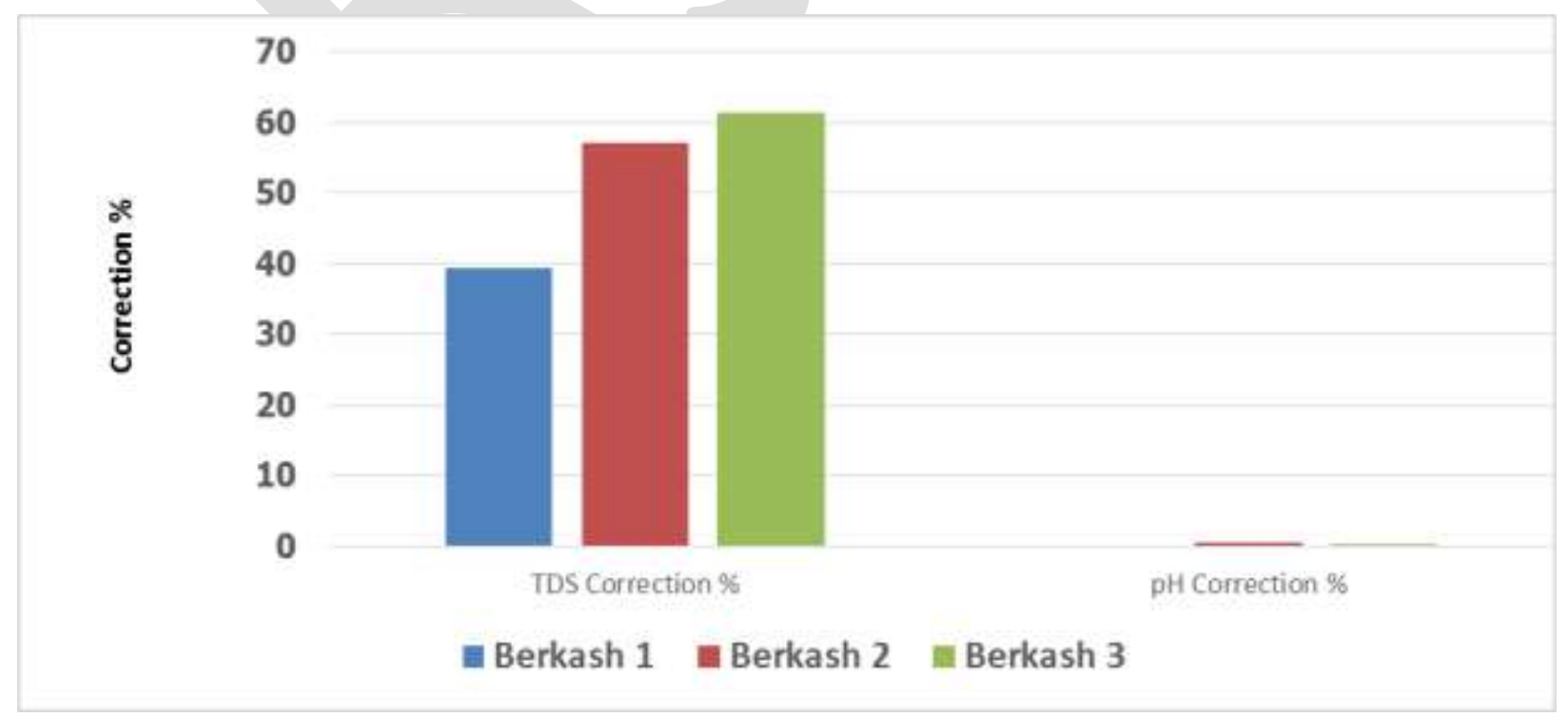

Figure 3: Water properties correction as a results of GAC/RO system ofBerkash region, Giza, Egypt stations for drinking water production through studying period of March, 2017 and June, 2018. 
Also, results show that this approach can be used in order to improve the quality of treated water and reduce the cost of the produced water by minimizing monitoring expenses granular activated carbon/ reverse osmosis (GAC/RO)equipment operation cost. Thus, this action plan allows the water treatment plant to integrate its environment, be eco-friendly and plays a great role in the sustainable management of water resources and therefore in regional sustainable developmentas shown in Figure 4.

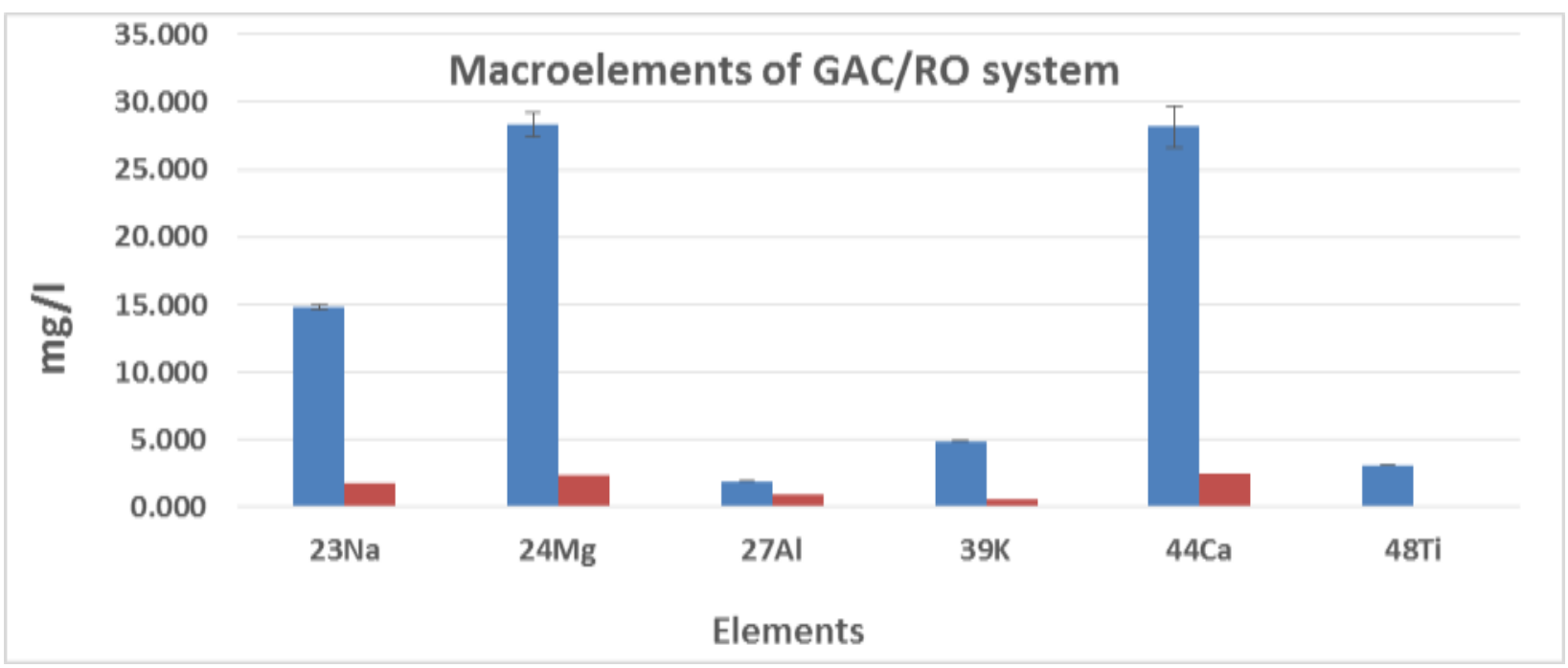

Figure 4: Macroelements composition of water before and after application of GAC/RO system ofBerkash region, Giza, Egypt stations for drinking water production through studying period of March, 2017 and June, 2018.

\section{CONCLUSION}

\section{From the results of this study are presented} as follow:

1. The resource waters have characterized and the metal concentrations of the surface and all ground waters were low to moderate quality according to classification of Flem et al., (2018).

2. $\mathrm{pH}$ and $\mathrm{EC}$ were not affected by the filtration for the mostparts. The only exception from this was the GAC/RO samples taken from the low TDS content ground water.

3. The performance of both sedimentation/filtration systems was highly dependent on the biological maturity of the system and surface water quality.

4. With a less TDS ground water contents, the performances of both chlorination and GAC/RO systems were highly efficiency systems.

5. In a $\mathrm{GAC} / \mathrm{RO}$ system operating in water conditions ( $<500$ TDS), reducing the treatment efficiency loading rate to $45 \%$ from $60-80 \%$ was important for achieving effluent quality more than $150 \mathrm{mg} / \mathrm{L}$ during events of low TDS content.

6. In case of system operating with only chlorination for groundwater, increased dosing loads resulted in a bad taste that required GAC filtration units after. 
7. In contrast, in a more mature system operating in warm water conditions (up to $37.5^{\circ} \mathrm{C}$ ), increased chlorine doses up to $2 \mathrm{mg} / \mathrm{l}$ resulted in good effluent performance.

\section{ACKNOWLEDGMENT}

This work was supported by funding from STDF, Egypt (Grant \# 2741). The authors wish to express their sincere gratitude to the Council for Scientific and Industrial research in University of Sadat city for providing lab space to execute this research work.

\section{REFERENCES}

Annamalai, J. Namasivayam, V. (2015) Endocrine disrupting chemicals in the atmosphere: Their effects on humans and wildlife, Environ. Int. 76: 78-97, http://dx.doi.org/10.1016/j.envint.201 4.12.006.

APHA (American Public Health Association), (2005). Standard Methods for the Examination of Water and Wastewater. 22nd ed. American Public Health Association, Washington, D.C.

Arivarasi R.Ganesan M. (2017) Seasonal variation in ground water quality and its suitability for drinking and agriculture, a case study in Kancheepuram region, Tamil Nadu, India. Global NEST Journal, 19 (1) 131-139.

Arras, W. Ghaffour, N. Hamou, A. (2009) Performance evaluation of BWRO desalination plant, a case study, Desalination 235 (1-3) 170-178.

Ghaffour, N. Missimer, T.M. Amy, G.L. (2013)Technical review and evaluation of the economicsof water desalination: current and future challenges for better water supply sustainability, Desalination 309: 197207.
Huerta, B. Jakimska, A. Llorca, M. Ruhí, A. Margoutidis, G. Acuña, V. Sabater, S. Rodriguez-Mozaz, S. Barcelò, D. (2015) Development of an extraction and purification method for the determination of multi-class pharmaceuticals and endocrine disruptors in freshwater invertebrates, Talanta 132: 373-381, http://dx.doi.org/10.1016/j.talanta.201 4.09.017.

Kalogirou, S. (2005)Seawater desalination using renewable energy sources, Prog. Energy Combust. Sci. 31 (3) 242-281.

Khanzada,N.K. Jamal Khan, S. Davies, P.A. (2017)Performance evaluation of reverse osmosis $(\mathrm{RO})$ pre-treatment technologies for in-land brackish water treatment. Desalination 406: 44-50.

Moghazy, H.M. Saleh, O.K. Rashwan, I.M. EI Tahan, N.E. (2015) Water management of Meet Yazied Canal, Kafr El-Shiekh governorate. Alexandria Engineering Journal 54, 1193-1205

Mousa, I.E. (2016) Total petroleum hydrocarbon degradation by hybrid electrobiochemical reactor in oilfield 
produced water. Marine Pollution

Bulletin 109: 356-360.

MWRI (Ministry of water resources and irrigation, Egypt), (2009) "Progress Report No.07", Integrated Irrigation Improvement and Management Project (IIIMP) July - December 2009.

Pal, A. He, Y. Jekel, M. Reinhard, M. Gin K.Y.H. (2014) Emerging contaminants of public health significance as water quality indicator compounds in the urban water cycle, Environ. Int. 71 (2014) 46-62, http://dx.doi.org/10.1016/j.envint..05. 025.

Piispanen, J.K., Sallanko, J. (2010) Mn(II) removal from groundwater with manganese oxide-coated filter media. Journal of Environmental Science and Health Part A Toxic/Hazardous Substances \& Environmental Engineering 45(13):1732-40.

Richard, R.K. Omondi, D.O. Wairimu, M.A. Maingi, M.S. (2016)Influence of rainfall intensity on faecal contamination in River Nyangores OF Mara basin, Kenya: An ecohealth integrity perspective. Asian Jr. of Microbiol. Biotech. Env. Sc. 18, (2) 281-289

Ruhí, A. Acuña, V. Barceló, D. Huerta, B. Mor, J.R. Rodríguez-Mozaz, S. Sabater, S. (2015) Bioaccumulation and trophic magnification of pharmaceuticals and endocrine disruptors in a Mediterranean river food web, Sci. Total Environ. 540; 250-259,

http://dx.doi.org/10.1016/j.scitotenv.2 015.06.009.

Tahir, M.A. Rasheed, H. Malana, A. (2008): A method development for arsenic analysis by modification in spectrophotometric technique. DrinkWater-Eng. Sci. Discuss., 1,135154. 